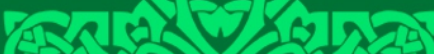
520030102 का 10 4 t

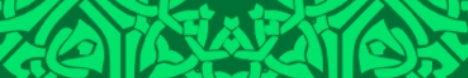
o 21205 रत्र 202 cos (2) 120

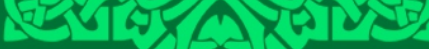
पis 4 कि

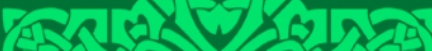
पित 1 (1) 0 (0)

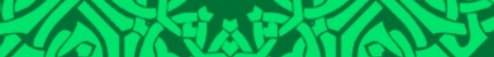
of 2505105 रन्तिए 0 cos 12 an

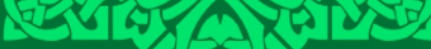
परत w कि Tat

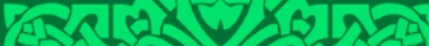
520100103 20 (1) 5 (5)
Sandra Dewi Dahlan, Mirotin Eka Wahyuningsih, Hasbi Assiddiqi, Edi Ardian, Rahmat Fajar The Role of Gossip as a Strategy to Reach Power in Tilik Short Movie

Hasaruddin, Sitti Mania, Ahmad Yani, Musyarif Tracking The Historical Development of Kedatuan Sawitto in South Sulawesi in The XVI-XVII Century

Abdul Muiz Amir, Sahiron Syamsuddin, Siswanto Masruri Dialectic Relationship Between The Qur'an and Hadith: The Interpretation of The Term "As-Sä'Ah" Using Critical Hermeneutic Analysis

Fachmi Alhadar, Safrudin Amin Covid-19 Poems as Cultural Response to Pandemic in Indonesia

Arini Indah Nihayaty, Bagong Suyanto, Sutinah A Study of Religious Symbols Attached to The Former Terrorist Convicts' Family as Seen in Social Interaction Wahyuddin, M. Abdul Hamid محاولات شوقي ضيف التجيديدية في تيسير النحو التعليمي

M. Napis Djuaeni, Hasyim Ashari نظام القافية ودوره في نشأَة المعاجم اللغوية العربية

Hasyim Haddade, Baso Pallawagau, Zaenal Abidin, Muhammad Zakir Husain التجديد في النحو: در اسة مذهب الخطيب الثربيني اللغوي في تفسيره السراج المنير

Nurhakki, Ahmad Sultra Rustan, Muhammad Taufiq Syam The Habituation of Tongkonan Communication as Adhesives for Religious Harmony in Toraja People

Nahdhiyah, Syahruni Junaid A Study of Al Qur'an towards Environmental Issues of Buginese ElongElong (Ecocritical Approach) UNIVERSITAS ISLAM NEGERI ALAUDDIN 


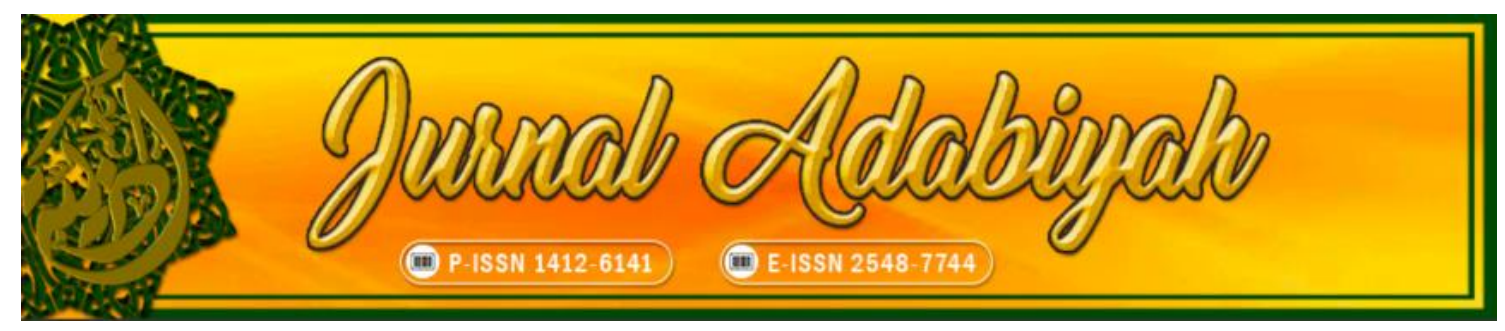

Theme: Humanities

VOLUME 21 NO. 1 JUNE 2021

\section{EDITOR-IN-CHIEF}

Nuri Emmiyati, Alauddin State Islamic University, Indonesia

\section{ASSOCIATE EDITOR}

Barsihannor, Alauddin State Islamic University, Indonesia

\section{INTERNATIONAL EDITORIAL BOARD}

Shamsi Ali, University of Northern California, United States

Miss Tiarne Jade Barratt, University of Sydney, Australia

Muhammad Widus Sempo, Universiti Sains Islam Malaysia, Malaysia

Salih Yousif Sharaf Mohamed, Al-Gazera University, Sudan

Aishah Waenaha Waemamah, Academy of Islamic and Arabic Studies Princess of Naradhiwas University

- Thailand, Thailand

\section{EXECUTIVE EDITOR}

Umar Thamrin, Alauddin State Islamic University, Indonesia

\section{MANAGING EDITOR}

Nasrum, Alauddin State Islamic University, Indonesia

\section{EDITORS}

Akbar Haseng, Institut Agama Islam Negeri Kendari, Indonesia Sardian Maharani Asnur, Alauddin State Islamic University, Indonesia Subehan Khalik Umar, Alauddin State Islamic University, Indonesia

Haniah, Alauddin State Islamic University, Indonesia

Andi Satrianingsih, Universitas Muhammadiyah Makassar, Indonesia

Awaluddin Syamsu, Universitas Muslim Indonesia

Muhammad Azwar, UIN Syarif Hidayatullah Jakarta, Indonesia

\section{ASSISTANT TO THE EDITORS}

Chusnul Chatimah Asmad, Alauddin State Islamic University, Indonesia

ENGLISH LANGUAGE ADVISOR

Rosmah Tami, Alauddin State Islamic University, Indonesia

Syahruni Junaid, Alauddin State Islamic University, Indonesia

\section{ARABIC LANGUAGE ADVISOR}

Muh. Saleh Syamsuri, Alauddin State Islamic University, Indonesia

Baso Pallawagau, Alauddin State Islamic University, Indonesia

\section{IT SUPPORT}

Taufiq Mathar, Alauddin State Islamic University, Indonesia

\section{COVER DESIGNER}

Nur Arifin 


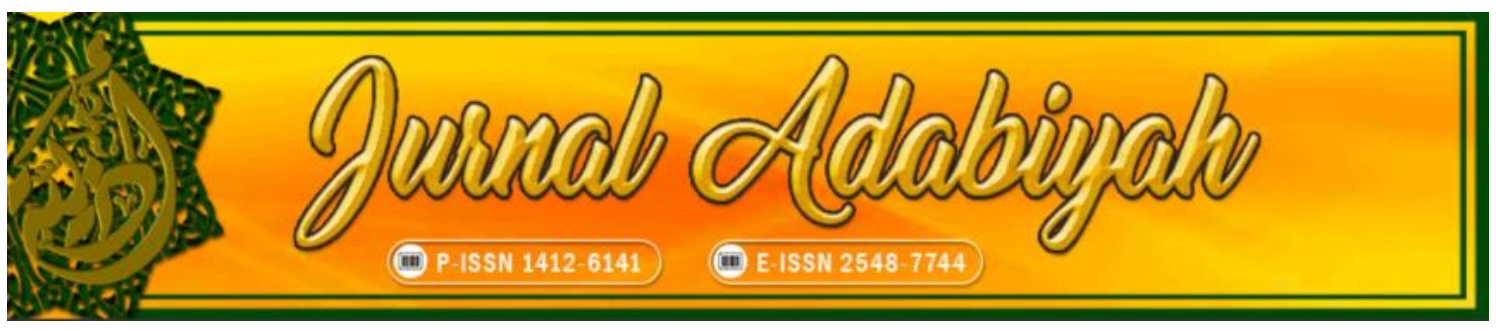

\section{Jurnal Adabiyah:}

This journal receives a national accreditation from Ministry of Research, Technology, and Higher Education Republic of Indonesia, Nomor 10/E/KPT/2019 on April 4, 2019 with the SINTA score: S2.

The Journal has been published by the Faculty of Adab and Humanity of Alauddin State Islamic University, Makassar, since 1997 and has been online since 2016 with the main themes on Humanities and Islamic Studies with the emphasis on interdisciplinary and intertextuality approach.

This journal are published twice a year, on June and December. The themes related to Islamic Studies are textual studies, scriptural traditions, Islamic law, and theology; and those related to Humanities are language, literature, history, and culture.

The journal of Humanities and Islamic Studies will provide the online collection of articles from 1997 up to now. The most updated information can be found on the website. 


\section{Table of Contents}

Besse Wahida, Khaerun Nisa Nuur, Ibnu Hajar Ansori

Tracing Entities of Arabic in The Qur'an

Sandra Dewi Dahlan, Mirotin Eka Wahyuningsih, Hasbi Assiddiqi,

Edi Ardian, Rahmat Fajar

The Role of Gossip as a Strategy to Reach Power in Tilik Short Movie

Hasaruddin, Sitti Mania, Ahmad Yani, Musyarif.

Tracking The Historical Development of Kedatuan Sawitto in South Sulawesi in The XVI-XVII Century

Abdul Muiz Amir, Sahiron Syamsuddin, Siswanto Masruri 57-81

Dialectic Relationship Between The Qur'an and Hadith: The Interpretation of The Term "As-Sā 'Ah" Using Critical Hermeneutic Analysis

Fachmi Alhadar, Safrudin Amin.

Covid-19 Poems as Cultural Response to Pandemic in Indonesia

Arini Indah Nihayaty, Bagong Suyanto, Sutinah

A Study of Religious Symbols Attached to The Former Terrorist Convicts' Family as Seen in Social Interaction

Wahyuddin, M. Abdul Hamid

محاولات شوقي ضيف التجبيليدية في تيسيل النحو الثعليهي

161-187

M. Napis Dj, Hasyim Ashari

نظام القافية ودوره في نشأة المعاجم اللغويا العربية

Hasyim Haddade, Baso Pallawagau, Zaenal Abidin,

Muhammad Zakir Husain

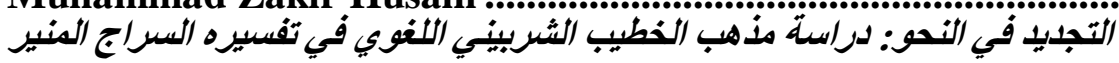

Nurhakki, Ahmad Sultra Rustan, Muhammad Taufiq Syam

The Habituation of Tongkonan Communication as Adhesives for Religious Harmony in Toraja People

Nahdhiyah, Syahruni Junaid

A Study of Al Qur'an towards Environmental Issues of Buginese ElongElong (Ecocritical Approach)

Jurnal Adabiyah Vol 21. Number 1/2021 


\title{
A STUDY OF RELIGIOUS SYMBOLS ATTACHED TO THE FORMER TERRORIST CONVICTS' FAMILY AS SEEN IN SOCIAL INTERACTION
}

\author{
Arini Indah Nihayaty ${ }^{1}$, Bagong Suyanto ${ }^{2}$, Sutinah ${ }^{3}$ \\ Universitas Airlangga Surabaya, Indonesia ${ }^{1,2,3}$ \\ Email: arini.indah.nihayaty-2018@fisip.unair.ac.id ${ }^{1}$, \\ bagong.suyanto@fisip.unair.ac.id², sutinah@fisip.unair.ac.id ${ }^{3}$
}

\begin{abstract}
This research discusses religious symbol attached to the former terrorist convicts' family as seen in social interaction. The theory applied in this study is George Herbert's the symbolic interactionism. This theory is used in analysing the phenomena in society because it is rooted in and focuses on the essence of humans as relational beings. This study is also reinforced by Erik H. Erikson's theory of psychosocial developmental stages and family sociology. The employed research method is qualitative method supported by interpretive paradigm. The data collection methods in this research are indepth interview, observation, field notes, and documentation. The locations in the study are the areas of Surabaya (including Sidoarjo), Malang and Probolinggo, which are known as the hideout locations of JAD (Jamaah Asharut Daulah) terrorist network. This study concludes that former terrorist convicts and their families still strongly embrace the religious symbols in the process of social interaction. The radicalization that occurs within the family is classified as a discourse, not an action. The resilience should be embraced by these former convict families to strengthen their existence as well as prevent them from returning to their groups. The government and all stakeholders must continue to provide guidance to the families of former terrorist convicts.
\end{abstract}

Keywords: Family; Psychosocial; Religious Symbols; Symbolic Interaction; Former Terrorist Convicts

$$
\begin{aligned}
& \text { ملخص } \\
& \text { تناقش هذه الدراسة الرموز الدينية للمدانين بالإرهاب السابقين وأسرهم. } \\
& \text { النظرية المستخدمة في هذه الدراسـة هي تفاعل رمزي أشاعاه جورج هربرت ميد. }
\end{aligned}
$$

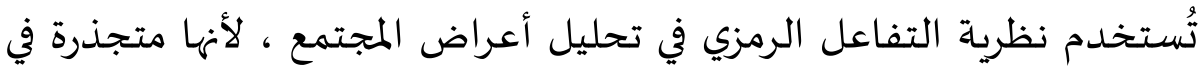

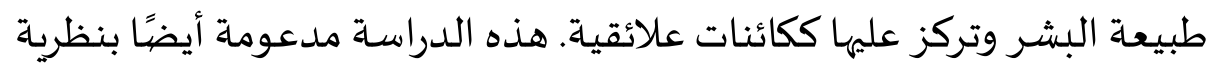

$$
\begin{aligned}
& \text { مراحل التطور النفسي والاجتماعي وعلم اجتماع الأسرة التي روج لها إريك }
\end{aligned}
$$


A Study of Religious Symbols Attached to The Former Terrorist Convicts' Family as Seen in Social Interaction

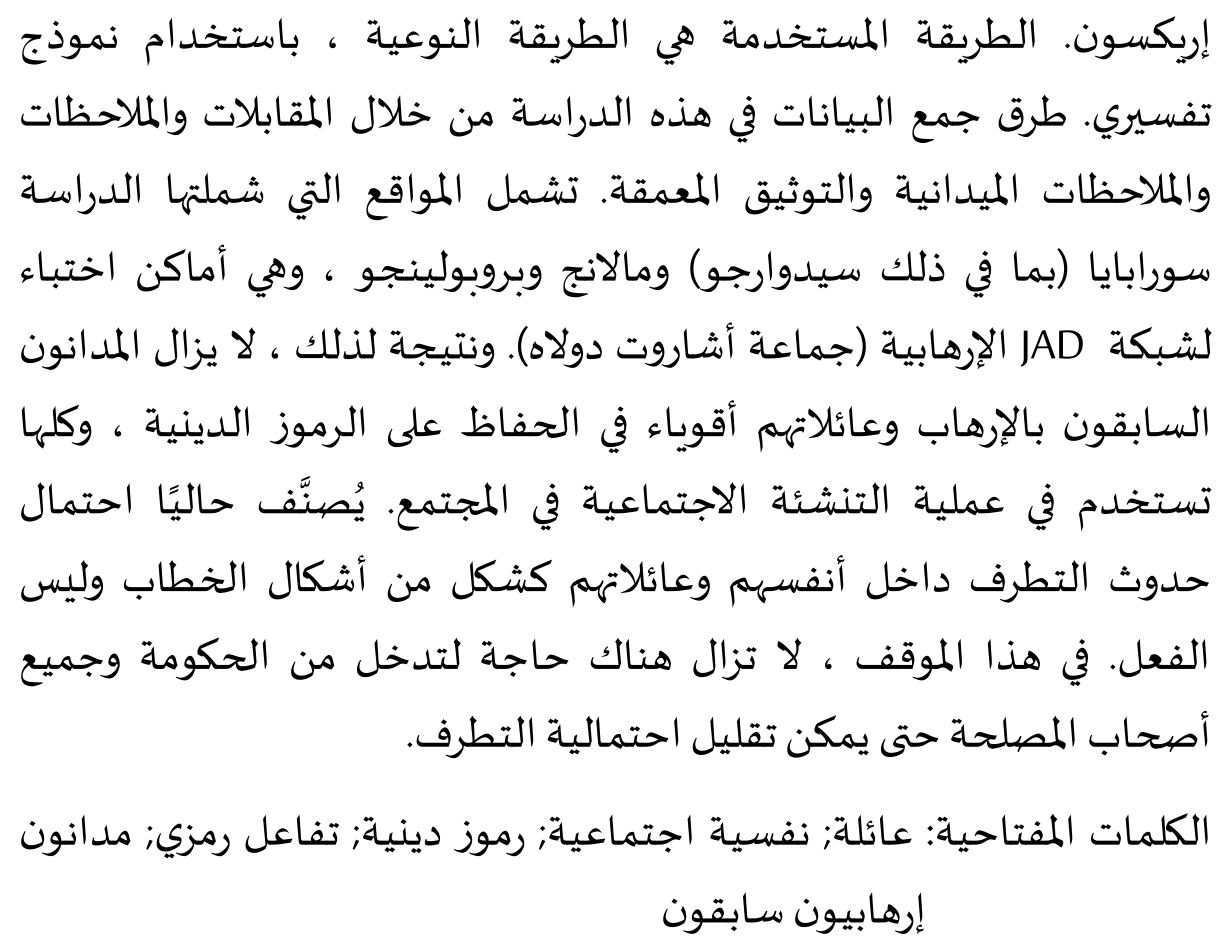

\section{Abstrak}

Penelitian ini membahas tentang simbol-simbol keagamaan dari mantan narapidana teroris dan keluarganya. Teori yang dipakai dalam kajian ini adalah interaksi simbolik yang dipopulerkan George Herbert Mead. Teori interaksi simbolik digunakan dalam menganalisis gejala masyarakat, karena berakar dan berfokus pada hakekat manusia sebagai makhluk relasional. Kajian ini juga didukung oleh teori tahap perkembangan psikolososial dan sosiologi keluarga yang dipopulerkan Erik H. Erikson. Metode yang digunakan adalah kualitatif, menggunakan paradigma interpretif. Metode pengumpulan data dalam penelitian ini dengan wawancara mendalam, observasi, catatan lapangan, dan dokumentasi. Lokasi dalam penelitian meliputi wilayah Surabaya (termasuk Sidoarjo), Malang dan Probolinggo yang merupakan lokasi dari persembunyian jaringan teroris JAD (Jamaah Asharut Daulah). Hasilnya, mantan narapidana teroris dan keluarganya masih kuat dalam mempertahankan simbol-simbol keagamaan, yang semua itu digunakan dalam proses sosialisasi dalam masyarakat. Potensi radikalisasi yang terjadi dalam diri mereka dan keluarga saat ini tergolong dalam bentuk wacana bukan aksi. Dalam posisi ini, tetap diperlukan intervensi dari pemerintah dan semua pemangku kepentingan agar potensi radikalisasi itu benar-benar bisa diminimalkan.

Kata Kunci: Keluarga; Psikososial; Simbol Keagamaan; Interaksi Simbolik; Mantan Narapidana Teroris 
Arini Indah Nihayaty, Bagong Suyanto, Sutinah
A Study of Religious Symbols Attached to The

Former Terrorist Convicts' Family as Seen in

Social Interaction

\section{A. Introduction}

The phenomenon of the specific religious symbols has been increasing recently, such as; a flag written the verse of Tauhid, syar'i veil, tauhid embroidery hat, the niqab, high water pants (wearing pants / trouser above the ankle), turban and other symbols. According to the Grand Imam of the Istiqal Mosque Prof. Nasaruddin Umar, the use of the niqab and high water pants (wearing pants / trouser above the ankle) of Muslims should not be an issue because wearing those symbols are part of human rights. It becomes wrong if those who wear the niqab and the high water pants degrade others who don't wear those.

Therefore, local wisdom as well as broad and deep knowledge in understanding the substance of Al-Quran and Hadith are needed to understand that the wearing of the niqab and the high water pants is an Arabic attribute. The wearing of niqab for woman and turban for man is part of the Middle East culture. Middle Eastern countries have a higher temperature than Indonesia. On the other hand, Canada has an extreme cold weather so that many women in that country wear long clothes covering almost part of their body even though they are not Muslims. Furthermore, if wearing a niqab is a mandatory, why the Prophet declares that a woman who performs Hajj should not wear niqab. A woman has to put off the niqab to complete the major pilgrimage (Hajj). ${ }^{1}$

The impact of using religious symbols has also resulted in the emergence of a commodification of religion. This contributes in the establishment of a new custom; the wearing of these attributes as religious expression to reflect religiosity. ${ }^{2}$ Understanding religion only through attached attributes will lead to an exclusivist attitude and radicalism of thought that is increasingly developing in society. ${ }^{3}$ This radicalism is a real threat to Indonesia. The development of radicalism has become the seed for the emergence of terrorism in the country. ${ }^{4}$

Acts of terrorism based on religion have occurred in Indonesia in the last 15 years. The most memorable incident is the Bali Bombing I which exploded at Paddy's club on October 12, 2002 which killed 202, mostly Australian citizens. This kind of terror has continued to this day. ${ }^{5}$ The horrendous case of terrorism occurred in the

${ }^{1}$ Nasaruddin Umar, "Reindonesianisasi Pemahaman Islam,” Detik News, last modified 2020, https://news.detik.com/kolom/d-4870589/reindonesianisasi-pemahaman-islam.

${ }^{2}$ Firdaus Wajdi, "Globalization and Transnational Islamic Education: The Role of Turkish Muslim Diaspora in Indonesian Islam,” Jurnal Adabiyah 18, no. 2 (2018): 176.

3 R. F. Rachman, "Perspektif Karen Armstrong Tentang Islamofobia Di Media Barat," Dakwatuna: Jurnal Dakwah dan Komunikasi Islam 4, no. 2 (2018): 282-291.

4 Atikah Mardhiya Rohmy, Teguh Suratman, and Arini Indah Nihayaty, "Peranan Tentara Nasional Indonesia Dalam Penindakan Terorisme Berbasis Agama," AT-TURAS: Jurnal Studi Keislaman 7, no. 1 (2020): 86-112.

5 Arini Indah Nihayaty and Bagong Suyanto, "Strategi Pembinaan Mental Masyarakat Dalam Menghadapi Radikalisme," Al-Tazkiah: Jurnal Bimbingan dan Konseling Islam 9, no. 2 (2020): 95112. 
suicide bombing case in Surabaya on May 13-14, 2018. The action involved the entire members of a family who carried out suicide bombings at 3 churches and killed 28 people and injured 57 people.

The other cases are the case in Sibolga, North Sumatra, which killed a woman and her 2-year-old child in 2019 and the Stabbing of Coordinating Minister for Political, Legal and Security Affairs, Wiranto, which was carried out by the JAD network (Jamaah Asharut Daulah) affiliated with ISIS (Islamic State of Iraq and Syria). Acts of terrorism in Indonesia are always highlighted by the confrontation of religious symbol, meaning and interpretation. Terrorism acts of JI always target objects related to a certain symbols, for example the bombings of police in Solo and Poso and the shooting of police in Kebumen and Purworejo.

In addition, a surprising incident of a suicide bomb happened in a mosque in Cirebon during Friday prayer. Religious symbols and meanings have always been contested by various parties, some use religion as a symbol of inspiration for social, economic, and political transformation movements, and some use religion as a symbol of an identity that is the basis for destructive goals. ${ }^{6}$ The religious symbols usage by the perpetrators in terrorism cases, especially those committed by radical Islamic groups, affects Muslims in Indonesia. Basically, perpetrators of terror must be separated from their religion because terrorism has nothing to do with religion. ${ }^{7}$

Islam is a religious teaching conveyed to its adherents by using the permanent symbols. The process of spreading Islam is normatively elitist, which means that the authority and competence to convey this teaching is only granted to those who are considered to meet certain requirements and criteria. However, pragmatically, the process of spreading Islamic teachings does not always conform to the normative discourse. In practice, the spread of religious teachings goes according to sociocultural developments. ${ }^{8}$ Multiple interpretations of religious messages are appeared due to the variations in the representation of Islamic teachings in the form of certain religious symbols that have been adapted to culture.

Basically, the cultural interpretation is the interpretation of symbols, because symbols are palpable, absorbed, general, and concrete. Religious symbols are symbols that synthesize and integrate "the world as lived and the world as imagined" and these symbols are useful for generating and strengthening religious beliefs. ${ }^{9}$ Symbols are a form of stimulation that contains meaning and values that can be learned by humans, and the human ability to respond symbols is in terms of meaning and value, not in

\footnotetext{
${ }^{6}$ Bruce Hoffman, Inside Terrorism (Columbia: Columbia University Press, 2017), 274.

7 Arini Indah Nihayaty and Atikah Mardhiya Rohmy, "Pemanfaatan Media Sosial Komunitas Untuk Menghadapi Konten Islam Ekstrim Di Internet,” Dakwatuna: Jurnal Dakwah dan Komunikasi Islam 6, no. 2 (2020): 213-227.

${ }^{8}$ Muhammad Amri, Risna Mosiba, and Saidna Zulfiqar Bin-Tahir, "Interreligious Tolerance in the Perception of Maluku Muslim Society," Jurnal Adabiyah 20, no. 1 (2020): 178-195.

${ }^{9}$ F.W Dillistone, Daya Kekuatan Simbol (Yogyakarta: Kanisius, 2002), 116.
} 
terms of physical stimulation of their senses. ${ }^{10}$ The meaning of a symbol, first of all, is not about its physical characteristics, but about what to do with the symbol. Another term developed by Shibutani is "the first and second behavior belongs to the property of the object". Thus, all symbolic objects denote a plan of action and that the reasons for behaving in a certain way towards an object are implied by those things. ${ }^{11}$

The symbol studied in this research is certain "religious symbol" which covers all attributes, symptoms or signs used to indicate human existence and certain characteristics of religion, including system of values and beliefs. ${ }^{12}$ Religious symbols can embody or condensed states of mind, feelings and values, but symbols can also refer to places, people or events in history. ${ }^{13}$ According to some experts, the meaning classifications of symbolic realism values by humans that occur in religion can be different from the religious practices adopted by religious user groups because religious practices in society can vary according to the community. Groups that call themselves 'rational groups' such as the people of the United States, Britain, France have a higher priority of religious practice compared to the symbolic aspects of religion. ${ }^{14}$

Regarding religious symbols, Geertz states that religion is: 1) a system of symbols which acts to 2) establish powerful, pervasive, and lasting moods and motivations in men by 3) formulating conceptions of a general order of existence and 4) clothing these conceptions with such an aura of factuality that 5) the moods and motivations seem uniquely realistic. ${ }^{15}$

Ridwan, on the religious symbols in the Islamic context, explains that the symbols are textual sources of religion in the form of permanent doctrines that cannot be changed based on religious interpreters' perspectives. ${ }^{16}$ This opinion is a form of Muslim scholars' disapproval to the hermeneutic interpretation method initiated by other Muslim scholars. Consequently, the characteristic of religious texts as permanent doctrines and resistant to new interpretations are still considered ineffective in preventing the dynamics and changes of developing interpretation of religious symbols.

10 Arnold Marshall Rose, "A Summary of Symbolic Interaction Theory," in Theories and Paradigms in Contemporary Sociology, ed. R. Serge Denisoff (Itasca: F. E. Peacock, 1974), 13.

${ }^{11}$ Tamotsu Shibutani, Society and Personality (Englewood Cliffs: Prentice Hall, 1961), 98.

12 Abdul Qodir Jailani and R. F. Rachman, "Kajian Semiotik Budaya Masyarakat: Nilai Keislaman Dalam Tradisi Ter-Ater Di Lumajang," MUHARRIK: Jurnal Dakwah dan Sosial 3, no. 2 (2020): 125-137. 2012), 56.

${ }^{13}$ Bryan Turner, Teori Sosial: Dari Klasik Sampai Postmodern (Yogyakarta: Pustaka Pelajar,

${ }^{14}$ Peter L. Berger, The Social Construction of Reality (Palatine: Anchor Book, 1966), 70.

${ }^{15}$ Hildred Geertz, Keluarga Jawa (Jakarta: Grafiti Press, 1973), 90.

${ }^{16}$ N.K. Ridwan, Agama Borjuis: Kritik Atas Nalar Islam Murni (Yogyakarta: Aruzz, 2004), 136. 
Regarding the dynamics of interpretation of religious symbols in Islamic teachings, Piliang states that to study matters closely related to communication requires understanding of religion in two forms of signs that are used and believed, including (1) signs is an ideological part that will not be accepted as something transcendent, and (2) sign which is a space for social cues is still very open to be interpreted differently. ${ }^{17}$

According to Nurcholish Madjid, there should be a separation between religion and symbols in the usage of religious symbols. This separation is in order to put both in a correct interpretation in order to avoid misunderstandings in encountering the diversities. This separation is important so that religious institutions and groups do not feel exclusive. Those who can speak Arabic will not feel having a higher rank; people are not easily offended because their religious symbols are insulted; and people without beards are not considered less pious compared to those who have ones.

Religion as an institution of belief that contains human faith and imagination in the form of human works and intentions (institutions, language, symbols and lifestyle), belief in supernatural existence, belief in the nature of life and death, and belief in the gods and other spirits who inhabit the supernatural world. The abstract manifests to be the concrete. Abstract teaching and concrete product of initiative are interrelated with one another. The two are connected in a relationship which is termed as "sacred sense". This sacred bond establishes institutions (organizations, associations, religious groups, etc.), language, symbols (logos, flags, etc.) and lifestyle (clothing, communication methods, gestures, etc.). Those establishments are often considered as sacred as the represented religion.

In the process of social interaction, the role of family is central. As the smallest unit in society, family consists several members mostly parents and children. Parents have an obligation to fulfill the needs of their children which include psychological needs, religious and spiritual needs, physical needs, and other needs. The establishment of a family's goal is to create the well-being for its members. A prosperous family is formed based on a legal marriage, the ability to accomplish proper physical and psychological needs, devotion to God Almighty, and harmonious, agreeable and balanced relations among the members of family, as well as decent relation among the family, the community and the environment. ${ }^{18}$

In the process of social interaction, the family of former terrorist convicts often receives a negative stigma because of their exclusiveness by displaying distinctive religious symbols from others. The religious symbols used include symbols for lifestyle (wearing the niqab for women and wearing high water pants and

17 Yasraf Amir Piliang, Hipersemiotik: Tafsir Cultural Studies Atas Matinya Makna (Yogyakarta: Jalasutra, 2003), 308.

${ }^{18}$ Herien Puspitawati, Gender Dan Keluarga: Konsep Dan Realita Di Indonesia (Bogor: PT Penerbit IPB Press, 2012), 2. 
having beard for men), gestures (reluctance to shake hands with someone other than their muhrim), using the term kafir ((takfiri) for other people who are not from their group), jihad, hijrah, bid'ah, and thogut, as well as the use of the flag and logo of Palestine. The use of symbols, both verbal (kafir, thogut, jihat, hijrah, amaliah) and nonverbal, in the family of ex-convicts certainly brings various consequences. They hardly socialize with others because their preference to gather with their own groups. These religious symbols are one of the reasons which define the former terrorist convict's family as exclusive and isolated in the process of interaction in society.

This article aims to look at changes in the behavior of ex-terrorist convicts' family in everyday life using George Herbert Mead's theory of symbolic interactionism. The focus of this research is the families of former terrorist convicts by looking at social interactions within the family (between parents and children) in creating and maintaining religious symbols. ${ }^{19}$ Furthermore, this study also analyzes the religious symbols in the families of former terrorist convicts by combining, associating, recording various behavioral situations, and revealing the interpretive processes of the former convicts' families.

The employed research method is qualitative method that uses one variant of interpretive paradigm which covers theory and procedures known as the symbolic interaction perspective (symbolic interactionism). The symbolic interaction perspective is inductive, which means it starts from special cases based on real experiences (speech or behavior of research subjects on certain research situations) to be formulated into models, theoretical concepts, pattern propositions, general categories or definitions or certain abstract themes. ${ }^{20}$

The data collection methods in this research are in-depth interview, observation, field notes, and documentation. The locations in the study are the areas of Surabaya (including Sidoarjo), Malang and Probolinggo, which are known as the hideout locations of JAD (Jamaah Asharut Daulah) terrorist network and have different terrorist typologies. Based on research, ISIS and JI networks are in Surabaya and Malang, while JAD network is in Probolinggo. The numbers of informants in this study are 11 families of ex-convicts in the three regions. These 11 families represent the former terrorist convicts who live in JAD hideout area. The number of research informants in each region was not determined before because this study focuses on the depth of variation and richness of data.

${ }^{19}$ Goerge Herbert Mead, Mind, Self and Society: From a Standpoint of Social Behaviorist, ed. Charles W. Morris (Chicago: University of Chicago Press, 1934), 224.

${ }_{20}$ Michael J. Driver and Siegfried Streufert, "Integrative Complexity: An Approach to Individuals and Group as Information-Processing Systems," Administrative Science Quarterly 14, no. 2 (1969): 272. 
A Study of Religious Symbols Attached to The

Former Terrorist Convicts' Family as Seen in

Social Interaction

Arini Indah Nihayaty, Bagong Suyanto, Sutinah

\section{B. Symbolic Interactionism in The Family}

There have been many studies on terrorism in relation to the family. Some researches emphasize the risk and resilience of families in the face of war and terrorism. Mass violence poses a significant threat to Individual and family mental health. Some experts state that unnoticed vulnerabilities within families also occur in the aftermath of the war and terrorism act. ${ }^{21}$ They develop a theory regarding the readiness of individuals and families to face trauma due to terrorism. Family resilience includes psychological state, illness and relationship difficulties, poverty, violence and loss of hope.

Stress and conflict generate trauma and fear linked to the threat for mental health. One of those is PTSD, a post-traumatic stress disorder. The Acts of terrorism, political violence and armed conflict or contemporary forms of war experienced by civilians, either as victims or as figures forced to take part in violence jeopardy the mental health. The theory of family psychology described by Ayten Zara reveals a relation among psychological health, emotional intensity for sadness and coping mechanism of family and friends of terrorist victims. ${ }^{22}$ This study employs the psychological theory of controlling stress and living normally and health theory of emotional stability maintenance after a terrorist attack suggested by The Two track Model of Bereavement, an adjustment in life after the death of a family member by continuing to live after a traumatic loss.

Anne Speeckhard (2008) reveals that the involvement and motivation of family members, either man or woman, in the suicide bombing do not differ significantly. Women's motivation in suicide bombings is influenced by revenge, nationalism, anger, negative identity, marginalization, and alienated feelings. Some of the advantages gained by terrorism groups by recruiting woman to perform suicide bombings are that woman attracts more media attention, increases public sympathy, is considered dodging officers' guard easier, and is more neglected because woman rarely sits in leadership positions.

Suyanto et al., study radicalization and de-radicalization in youth groups employing "Technologies of the Self" of Michel Foucault's, four radicalization phases developed by Mitchell D. Silber and Arvin Bhatt (pre-radicalization, selfidentification, indoctrination, and jihadization), and the theory of radicalization of Aly and Striegher. The results show that changing dynamics not only strike when there is a shifting from a pre-radicalization phase toward the self-identification phase as a member of a radical group (in borrowing a term from Silber and Bhatt), but also when they are already involved within the radical group. This article which is entitled

${ }^{21}$ Shapiro R. Lauren and John Jay, "Women's Radicalization to Religious Terrorism: An Examination of ISIS Cases in the United States," Islamic States Online Activity and Response 42, no. 1-2 (2019): 88.

${ }^{22}$ Ayten Zara, Grief Intensity, Coping and Psychological Health among Family Members and Friends Following a Terrorist Attack, Death Studies (London: Routledge \& Kegan Paul, 2019), 366. 
Arini Indah Nihayaty, Bagong Suyanto, Sutinah
A Study of Religious Symbols Attached to The

Former Terrorist Convicts' Family as Seen in Social Interaction

"Pseudo-Radicalism and the De-Radicalization of Educated Youth in Indonesia" concludes that "there is no single pathway to radicalization and no distinct pattern to profile an individual throughout any of the stages of radicalization". 23

Rolf Halse conducts a textual analysis in his research entitled The MuslimAmerican neighbor as terrorist: The representation of a Muslim family in 24 uncovering a change in the Muslim stereotype in US TV entertainment post-9/11. ${ }^{24}$ The textual analysis in this series (organization and narrative style) focuses on the negative stereotypes of the Muslim family. The Representation displayed refers to the thought of orientalism. Edward W. Said establishes the orientalism as critical concept, marked by the most important orientalism dogmas of how the east is depicted by western perspective, for example the systematic difference between the East as an irrational, underdeveloped, inferior nation and the West as a rational, developed, and advanced nation.

The explanation of previous studies above proves that this research is different and new. The focus of this research is on the family of former terrorist convicts to see the use of certain religious symbols in social interactions. The theories used in this research are George Herbert Mead's theory of symbolic interactionism, Erik H. Erikson's theory of psychosocial development stages, and family sociology theory to see the stages of behavior transformation (roles, functions and parenting styles) to analyze the use of religious symbols of former terrorist convicts' family in the process of social interaction.

George Herbert Mead conceives symbolic interactionism that declares the position of symbols in the circle of social life. ${ }^{25}$ The meaning of non-verbal and verbal messages affects the minds of the people who are interacting. The symbol in this circle is used in communicating to convey the message intended by the actor. The process of understanding this symbol is a process of interpretation in communicating, such as one of the premises developed by hermeneutics which states that basically, human life is understanding and all human beings' understanding of life is possible because humans interpret it, whether consciously or not. ${ }^{26}$

Verbal communication is quite complex. Symbol or verbal message is a type of symbol that uses one or more words. Almost all speech stimuli are part of deliberate verbal messages category; a conscious attempt to relate to other people by a system of verbal codes called language. Language can be defined as a set of symbols,

${ }^{23}$ Bagong Suyanto, Mun'im Sirry, and Rahma Sugihartati, Pseudo-Radicalism and the DeRadicalization of Educated Youth in Indonesia Studiesin Conflict \& Terrorism (London: Routledge \& Kegan Paul, 2019), 1-20.

${ }^{24}$ Rolf Halse, "The Muslim-American Neighbour as Terrorist: The Representation of a Muslim Family in 24," Journal of Arab \& Muslim Media Research 5, no. 1 (2012): 3.

25 Bernard N. Meltzer, "Meads Social Psychology," in Symbolic Interaction: A Reader in Social Psychology, ed. Jerome G. Manis and Bernard N. Meltzer (Boston: Allyn \& Bacon, 1978), 38.

${ }^{26}$ Umiarso and Elbadiansyah, Interaksionisme Simbolik Dari Klasik Hingga Modern (Jakarta: PT. Raja Grafindo Persada, 2014), 63. 
with rules for combining these symbols, which are used and understood by a community. ${ }^{27}$

Nonverbal communication is the process of communicating messages without using words. Examples of nonverbal communication are the use of gestures, body language, facial expressions and eye contact, the usage of objects such as clothes, haircuts, symbols, as well as ways of speaking including intonation, emphasis, voice quality, emotional style, and speaking style. Experts in the field of nonverbal communication usually use the definition of "not using words" strictly, and do not equate non-verbal communication with non-oral communication. ${ }^{28}$

Mead defines the process of thinking as an internalized conversation of the individual with himself. The process of thinking is a social phenomenon. It arises and develops through social process and is an integral part of that process. Social processes are prior to thought; social processes are not the products of thought. Through the processes of interacting with oneself, individuals choose which of the stimuli they will respond to. After that, one will try various responses in mind, before really decides what response is appropriate and in accordance with the stimulus that comes. ${ }^{29}$ Thinking is the interaction of oneself with other people. Thinking cannot be separated from the social situation setting. ${ }^{30}$

Mead's view of "self" lies in the concept of "taking on others' roles". Mead's concept of self is a translation of "the social self". For Mead and his followers, individuals are active and innovative; not only socially created, but also creates a new society whose behavior cannot be predicted. Individuals control their own actions and behavior, and the control mechanism lies in social construction. Accordingly, the self is related to the process of self-reflection, which is generally referred to as self-control or self-monitoring. It is through self-reflection that, according to Mead, individuals are able to adjust to the circumstances in which they are in, as well as adjust the meaning and effects of the actions they take. In other words, people are implying themselves from the other person's point of view.

Symbolic interactionism occupies a unique and important position in family studies. The theoretical perspective development of symbolic interactionism in family studies began in the 1920s and 1930s. Burgess was the first to apply the systematic application of "processual" symbolic interactionism to family studies. ${ }^{31} \mathrm{He}$ proposes that the family is as a "unity of interacting personalities," a small universe of

${ }^{27}$ Deddy Mulyana, Metodologi Penelitian Kualitatif: Paradigma Bari Ilmu Komunikasi Dan Ilmu Sosial Lainnya (Bandung: Remaja Rosdakarya, 2018), 68.

${ }^{28}$ Jalaluddin Rakhmat, Psikologi Komunikasi (Bandung: PT. Remaja Rosdakarya, 2000), 285.

${ }^{29}$ George Ritzer and Douglas J. Goodman, Teori Sosiologi: Dari Teori Sosiologi Klasik Sampai Perkembangan Mutakhir Teori Sosial Posmodern (Yogyakarta: Kreasi Wacana, 2010), 385.

${ }^{30}$ Umiarso and Elbadiansyah, Interaksionisme Simbolik Dari Klasik Hingga Modern (Jakarta: PT Raja Grafindo Persada, 2014), 189.

${ }^{31}$ Ernest W. Burgess, "The Family As A Unity Of Interacting Personalities," The Family 7, no. 1 (1926): 3. 
communication in which roles and each personality influence every other personality. Another researcher who utilizes symbolic interactionism approach to the family is Willard Waller (1937, 1938). Waller employs qualitative methods to study family dynamics, particularly processes of interpersonal conflict, bargaining, and exploitation. ${ }^{32}$

In addition, the contemporary family studies employing symbolic interactionism deals with several types of analysis of family roles, roles of husband and wife, gender roles, transitional parental roles and interaction patterns, attitudes, dispositions, and self-concept of family members. The concept of role is also important for most of the major sociological perspectives (structural theory, social exchange theory, and conflict theory). Symbolic interactionism emphasizes the process of defining, negotiating and identifying roles in the family. ${ }^{33}$

The first interaction experienced by humans is the interaction with the nuclear family. When there is interaction, there is also socialization which according to Berger is a process of a child becoming a member who participates in society. ${ }^{34}$ Furthermore, Durkin states that socialization is a process of transmitting values, belief systems, attitudes, and behaviors from one generation to the next with the aim that the next generation has a value system in accordance with the demands of the desired norm. ${ }^{35}$

Most research on socialization focuses on developing several aspects of the self (self-esteem, gender, and family identity). This study shows a positive assessment that reflects from parents. Parental support and the use of inductive control result in positive socialization of the child's self-concept. ${ }^{36}$ The reciprocal socialization process between parents and children affects the self-concept of others. The high level of reciprocity that is a hallmark of the socialization process (and a feature of symbolic interactionism) is rarely reflected in family research, even though researchers have become increasingly sensitive to it. A focus on reciprocity is seen in research on problematic negotiating identities, as in the case of lesbian motherhood or in the case of immigrant families with separated parents and children (children have to negotiate their problems in a foreign cultural context). ${ }^{37}$ In addition to pursuing traditional

${ }^{32}$ Lindsey D. Nelson, “Herbert Blumer's Symbolic Interactionism. University of Colorado at Boulder Spring," Colorado.Edu, last modified 1998, accessed January 5, 2020, http://www.colorado.edu/ Communication /metadiscourses/Papers/ App_Papers/Nelson.htm.

${ }^{33}$ Kamaluddin Tajibu, "Pasang Ri Kajang in Developing Youth Character of Environmental Love in Tana Toa Kajang," Jurnal Adabiyah 20, no. 1 (2020): 131.

${ }^{34}$ Berger, The Social Construction of Reality, 72.

35 K. Durkin, Developmental Social Psychology From Infancy To Old Age (New York: Blackwell Publisher Inc, 1995), 149.

${ }^{36}$ Abd Rahman, "Family Resilience in Islamic Perspective (A Case Study of Parent and Child Interaction Behavior in the District of Somba Opu Gowa)," Jurnal Adabiyah 20, no. 2 (2020): 351.

37 Amy L. Hequembourg and Michael P. Farrell, "Lesbian Motherhood: Negotiating Marginal-Mainstream Identities," Gender \& Society 13, no. 4 (1999): 540. 
interests in family studies, mostly in the United States, symbolic interactionism is increasingly pursuing cross-cultural and international research.

Steve Derne (1999) studies self and identity by researching how male filmgoers in India use their interpretations of Western films to maintain and enhance their sense of pride. The concept or ethnic identity of a person is involved in the interpretive process which serves to incorporate ideas into existing self-structures. Research in Nigeria by Rotini (1986) concludes that car ownership becomes status symbol that influences the form of personal interaction among the owners of various types of cars. The research also discusses the infiltration of new technology into culture, relation and roles in social institutions such as family, law, and religion.

Theoretically, a person will display certain symbols to present the identity in front of the public. However, the displayed symbol is not always the true-self. Realistically, the efforts to present certain symbols affect people around. Moreover, if the person is the head of the family, he has the power to doctrine other members on the symbols or images to be displayed in public. In other words, the implementation of symbolic interactionism in a family of ex-terrorist convicts shows that the influence is delivered from and to the family members.

\section{Family Function and Psychosocial Development Stages}

Indonesia is an archipelago consisting of 19,000 islands and 200 ethnolinguistic groups. ${ }^{38}$ The 1998 crisis in Indonesia has changed the structure and function of the family in this country because of the reformation in economic and social field. Basically, the generalization of changes in family function is indeed inappropriate given the diversity of cultures in Indonesia, so that the traditional form of a family varies greatly. ${ }^{39}$ Nevertheless, it can be said that the family remains the main unit of social organization in Indonesia despite the changes in the past few decades.

Of the several types of changes that occur, the most fundamental change is a shift from an emotionally extended family to a nuclear family. ${ }^{40}$ This shift does not refer to the arrangement of the area in which a family lives, but rather to the main functions, loyalties and obligations of family members. In the traditional extended family system, the main loyalty of the family is given to parents, so that the head of the family controls all aspects of life, from earning a living to determining partners for their children to marry.

${ }^{38}$ Fatiyah, "Pemahaman Santri Terhadap Nilai-Nilai Pancasila," Jurnal Adabiyah 17, no. 1 (2017): 44

39 Andi Nirwana and Muhammad Rais, "Toleransi Antar Umat Beragama Islam Dan Kristen Pada Masyarakat Kelurahan Paccinongang Kecamatan Somba Opu Kabupaten Gowa,” Jurnal Al Adyaan; Jurnal Sosial dan Agama 6, no. 2 (2020): 185.

${ }^{40}$ Graeme Hugo, "Effects of International Migration on the Family in Indonesia," Asian and Paciific Migration Journal 11, no. 1 (2002): 13-46. 
Arini Indah Nihayaty, Bagong Suyanto, Sutinah
A Study of Religious Symbols Attached to The

Former Terrorist Convicts' Family as Seen in

Another factor in the transition of extended to the nuclear family is the shift in the role and status of woman in several regions in Indonesia. In traditional society, woman's duties were giving birth and caring for children. The presence of the mass media and the equality of education have encouraged women to question their traditional roles and status. In addition, the increasing commercialization of agriculture and the development of industrialization have opened up a wider economic role for women. Not only involved in formal work, women are now also involved in determining the number of children (through the family planning program), as well as determining the time to have children.

The duties and functions of the family are singular as well as plural. Accordingly, Family functions include maintaining harmony, providing financial stability, and educating children (physical, psychological, and religious education). Haron Hunt (in Vembriarto, 1982: 44) expresses the three family functions; biological function, affection function, and socialization function. The function of biology as the first function defines the family as the birthplace of children. Second, the function of affection is a social relationship that is filled with intimacy and warmth in the family. This affective relationship grows as a result of the loving relationship as the basis of marriage. Third, the socialization function indicates the role of the family in shaping the child's personality. Through social interaction in the family, children learn the behavior, attitudes, beliefs, ideals and values of society in the context of personality formation.

According to Santrock, parenting is a method used by parents to educate their children to be socially mature individuals. ${ }^{41}$ Parents should raise their children and set a good example. Consciously or unconsciously, parents' behavior will be imitated by their children directly or indirectly because parents are the closest figure to the children. As Hurlock states the treatment of parents towards children will affect children's attitudes and behavior. Parenting patterns are expected to shape the child's personality in socializing in society.

The development experienced by each person greatly influences the formation of the family. This psychosocial development for individuals consists of several stages starting from the baby to the age of above 65 years. Erik H Erikson categorizes the eight stages of psychosocial development experienced by humans. ${ }^{42}$ First stage is infancy (oral-sensory, under 2 years). At this stage, a child learns to trust without removing suspicion. A child with the confidence will feel safe under the protection of their parents. In reality, some parents are over protective which grow hesitation in children. On the contrary, some parents do not provide sufficient protection that makes children feel insecure and experience a crisis of trust. Second stage is muscular-anal (toddlerhood, 2-3 years). At this stage, patience and tolerance are the basic to support children development. A child will balance the obtained freedom and

\footnotetext{
${ }^{41}$ John W. Santrock, Perkembangan Anak (Jakarta: PT Erlangga, 2007), 163.

${ }^{42}$ Erik H. Erikson, Childhood and Society (New York: WW Norton \& Company, 1993), 291.
} 
get rid of shame and doubt. Third stage is locomotor-genital (early childhood, 3-6 years). At this stage, a child learns to take the initiative without feeling guilty. Occasionally, some people have the wrong perception by labeling them as a bad child At this stage, a child has various initiatives and ideas, then try to turn those into reality. Fourth stage is latency (middle childhood, 7-12years). At this stage, a child learns to enter the world of formal education. The child must control the sense of imagination and replace it with education, but the imagination will not completely disappear.

The fifth stage is adolescence (12-19 years). Puberty and desire to seek identity in order to avoid confusion are undergone at this stage. Those who attain success at this stage will find the goal that is called by Erikson as fidelity. The Sixth Stage is early adulthood (20-39 years). The problem in this stage is isolation, the tendency to isolate oneself from all things, either from love or friendship or the community. At this stage, an individual has the ability to be closer to other people, such as lovers and friends.

Seventh stage is middle adulthood (40-59 years). At this stage, the individual manages a balance between the excitement of life and boredom. Being successful going through this stage, people will care for others who giving a hand through one's lifetime. Eighth stage is late adulthood (60 years and above). The psychosocial crisis experienced by individuals at this stage is related to integrity and disappointment. One will try to develop ego integrity with the least amount of despair. The basic value of life that will be obtained after going through this crisis is wisdom.

The heads of families of former terrorists educate their children based on their believed ideology. In this context, the role of the family in individual education is implemented. After all, the elders in a family have the opportunity to shape the character of the children. On the other hand, referring to the theory of stages of psychosocial development, each ex-convict experiences a change in mindset over time. At a relatively young age or in the early stages of psychosocial development, the passion for committing the terror acts (which they believe as the holy path) is much more intense compared to in the present, at the time they have children. Their understanding also has developed which eventually become the aspects of consideration in making decisions, especially in the worship matters and family management.

\section{The Religious Symbols Usage of Former Terrorist Convicts' Family in Social Interaction}

The use of religious symbols in the family of former terrorist convicts is divided into two, verbal and nonverbal religious symbols. Verbal and nonverbal communication is an inseparable unit, because those create a meaning together. According to Adler and Rodman, this limitation is a step to distinguish vocal 
Arini Indah Nihayaty, Bagong Suyanto, Sutinah
A Study of Religious Symbols Attached to The

Former Terrorist Convicts' Family as Seen in Social Interaction

communication, which means acts of communication that use mouth and verbal communication, which means acts of communication that uses words. ${ }^{43}$

Thus, the definition of nonverbal communication is oral and non-oral messages expressed by other than linguistic means. Verbal communication consists of spoken and written languages. Non-verbal communication consists of tone of voice, sighs, screams, vocal quality, cues, movements, appearance, and facial expressions. This study selects 11 informants who were former terrorist convicts. Those from Surabaya are AF, D, and F, those from Malang are S and T, those from Probolinggo are $\mathrm{W}, \mathrm{I}, \mathrm{B}, \mathrm{E}, \mathrm{D}$, and $\mathrm{Y}$ is from Sidoarjo. Informants $\mathrm{E}$ and $\mathrm{D}$ could not be interviewed directly, so the researcher switched to interviewing their families, especially their wives. The religious symbols of former terrorist convicts and their wives can be classified based on the types of non-verbal communication.

Table 1

Observation on 11 former terrorist convicts and their families

\begin{tabular}{|c|c|c|c|c|}
\hline No & $\begin{array}{c}\text { The } \\
\text { former } \\
\text { terrorist } \\
\text { Convicts }\end{array}$ & $\begin{array}{c}\text { Visual } \\
\text { Observation } \\
\text { (gestures, eye } \\
\text { gaze, and facial } \\
\text { expressions) }\end{array}$ & $\begin{array}{c}\text { Auditif } \\
\text { Observation } \\
\text { (tone, volume, } \\
\text { pace, and rhythm } \\
\text { of speech) }\end{array}$ & $\begin{array}{l}\text { Art } \\
\text { Obs } \\
\text { (app }\end{array}$ \\
\hline 1 & $\begin{array}{l}\text { AF, male, } \\
55 .\end{array}$ & $\begin{array}{l}\text { AF was reclusive } \\
\text { and kept a distance } \\
\text { from others. A } \\
\text { look of sadness } \\
\text { crossed his face } \\
\text { while telling the } \\
\text { stories. } \\
\text { Meanwhile, his } \\
\text { wife always gave a } \\
\text { sharp eye gaze and } \\
\text { was unhappy to be } \\
\text { interviewed. }\end{array}$ & $\begin{array}{l}\text { AF's voice volume } \\
\text { was low, he } \\
\text { stammered and his } \\
\text { rhythm was } \\
\text { medium. His wife } \\
\text { spoke very loud } \\
\text { with a high } \\
\text { intonation, } \\
\text { although the } \\
\text { rhythm } \\
\text { medium. }\end{array}$ & $\begin{array}{l}\text { AF wore a koko, } \\
\text { high water pants, } \\
\text { had a beard, and had } \\
\text { a black mark on his } \\
\text { forehead. } \\
\text { Meanwhile, his wife } \\
\text { wore a large size of } \\
\text { Muslim robe and } \\
\text { veil, and without } \\
\text { putting make up on } \\
\text { her face. }\end{array}$ \\
\hline 2 & $\begin{array}{l}\mathrm{D}, \quad \text { male, } \\
41 .\end{array}$ & $\begin{array}{l}\text { D was fiery, had } \\
\text { sharp gaze, and } \\
\text { maintained a } \\
\text { distance from } \\
\text { others. While his } \\
\text { wife was reclusive, }\end{array}$ & $\begin{array}{l}\text { D's voice was } \\
\text { loud, his intonation } \\
\text { was high, and his } \\
\text { rhythm was rather } \\
\text { fast. His wife } \\
\text { spoke in a low }\end{array}$ & $\begin{array}{l}\text { D wore a robe } \\
\text { (jubah), he had a } \\
\text { thin beard, and had } \\
\text { a black mark on his } \\
\text { forehead. His wife } \\
\text { wore a large size of }\end{array}$ \\
\hline
\end{tabular}

${ }^{43}$ Ronald B Adler and George Rodman, Understanding Humas Communication (New York: Oxford University Press, 2014), 96. 


\begin{tabular}{|c|c|c|c|c|}
\hline & & $\begin{array}{l}\text { her gaze was not } \\
\text { as sharp as D, and } \\
\text { she was not very } \\
\text { expressive. }\end{array}$ & $\begin{array}{l}\text { volume and } \\
\text { medium rhythm. }\end{array}$ & $\begin{array}{l}\text { dark Muslim robe } \\
\text { and veil without } \\
\text { putting make up on } \\
\text { her face. } \\
\end{array}$ \\
\hline 3 & 33 & $\begin{array}{l}\text { F was more } \\
\text { sociable, } \\
\text { expressionless, and } \\
\text { had a casual gaze. } \\
\text { While his wife was } \\
\text { reclusive, kept a } \\
\text { distance with } \\
\text { others and had } \\
\text { wistful eyes. }\end{array}$ & $\begin{array}{l}\text { F's voice was } \\
\text { medium, with flat } \\
\text { intonation and } \\
\text { moderate rhythm. } \\
\text { Meanwhile, his } \\
\text { wife spoke in a } \\
\text { moderate volume } \\
\text { as well as a } \\
\text { moderate } \\
\text { intonation. }\end{array}$ & $\begin{array}{l}\text { F wore casual attire, } \\
\text { pants and T-shirts, } \\
\text { and had a black } \\
\text { mark on the } \\
\text { forehead. His wife } \\
\text { was dressed in a } \\
\text { large size of bright } \\
\text { Muslim robe and } \\
\text { veil, without putting } \\
\text { make up on her } \\
\text { face. }\end{array}$ \\
\hline 4 & $\begin{array}{l}\mathrm{Y}, \quad \text { male, } \\
51 .\end{array}$ & $\begin{array}{l}\text { Informant Y was } \\
\text { reclusive, kept his } \\
\text { distance from } \\
\text { others. He was } \\
\text { rather unwelcome } \\
\text { while delivering } \\
\text { the answer for the } \\
\text { interview. While } \\
\text { his wife had rather } \\
\text { sharp eye gaze } \\
\text { with ordinary look. }\end{array}$ & $\begin{array}{l}\text { Y's voice was low } \\
\text { with a moderate } \\
\text { rhythm. } \\
\text { Meanwhile, his } \\
\text { wife had a slightly } \\
\text { high tone, little } \\
\text { loud and moderate } \\
\text { rhythm. }\end{array}$ & $\begin{array}{l}\text { Y wore koko with } \\
\text { short pants, and had } \\
\text { a beard and had } \\
\text { black mark on his } \\
\text { forehead. } \\
\text { Meanwhile, his wife } \\
\text { wore a large size of } \\
\text { dark robe and veil } \\
\text { without putting } \\
\text { make up on her } \\
\text { face. }\end{array}$ \\
\hline 5 & 9. & $\begin{array}{l}\text { Informant } \mathrm{S} \text { was } \\
\text { quite sociable, } \\
\text { expressionless and } \\
\text { had casual gaze. } \\
\text { While his wife } \\
\text { kept her distance. } \\
\text { She did not like } \\
\text { the interviewer's } \\
\text { arrival. }\end{array}$ & $\begin{array}{l}\text { S's voice was } \\
\text { moderate, his } \\
\text { intonation was flat, } \\
\text { the rhythm was } \\
\text { moderate. } \\
\text { Meanwhile, his } \\
\text { wife's voice had a } \\
\text { high volume with a } \\
\text { medium } \\
\text { intonation. }\end{array}$ & $\begin{array}{l}\text { S wore pants and } \\
\text { shirt. There was a } \\
\text { black mark on his } \\
\text { forehead. } \\
\text { Meanwhile, his wife } \\
\text { wore up-to-date } \\
\text { Muslim dress and } \\
\text { veil and wore } \\
\text { complete make-up. }\end{array}$ \\
\hline 6 & T, male, 39 & $\begin{array}{l}\text { Informant } \mathrm{T} \text { was } \\
\text { quite sociable, } \\
\text { expressionless and } \\
\text { had casual gaze. }\end{array}$ & $\begin{array}{l}\text { T's voice had high } \\
\text { intonation and } \\
\text { moderate rhythm }\end{array}$ & $\begin{array}{l}\text { T wore pants and a } \\
\text { long shirt. There } \\
\text { was a black mark on } \\
\text { his forehead. The } \\
\text { interviewer was }\end{array}$ \\
\hline
\end{tabular}




\begin{tabular}{|c|c|c|c|c|}
\hline & & & & $\begin{array}{l}\text { unsuccessful in } \\
\text { meeting T's wife. }\end{array}$ \\
\hline 7 & $\begin{array}{l}\text { W, male, } \\
38 .\end{array}$ & $\begin{array}{l}\text { W was reclusive } \\
\text { and kept a distance } \\
\text { from others. A } \\
\text { look of sadness } \\
\text { crossed his face } \\
\text { while telling the } \\
\text { stories. While his } \\
\text { wife had rather } \\
\text { sharp gaze and } \\
\text { displayed } \\
\text { discontentment. }\end{array}$ & $\begin{array}{l}\text { W's voice was low } \\
\text { with moderate } \\
\text { rhythm. }\end{array}$ & $\begin{array}{l}\text { W wore koko, high } \\
\text { water pants, had a } \\
\text { beard and a black } \\
\text { mark on his } \\
\text { forehead. His wife } \\
\text { wore a large size of } \\
\text { black robe and veil } \\
\text { without wearing any } \\
\text { make up. }\end{array}$ \\
\hline 8 & male, 44 . & $\begin{array}{l}\text { I was sociable, } \\
\text { expressionless, } \\
\text { kept the distance } \\
\text { from others, and } \\
\text { had sharp eye } \\
\text { gaze. His wife was } \\
\text { reclusive, had } \\
\text { ordinary } \\
\text { expression and } \\
\text { gaze. }\end{array}$ & $\begin{array}{l}\text { I's voice was } \\
\text { moderate, his } \\
\text { intonation was flat, } \\
\text { and his rhythm } \\
\text { was moderate. } \\
\text { Meanwhile, his } \\
\text { wife had low voice } \\
\text { with moderate } \\
\text { intonation. }\end{array}$ & $\begin{array}{l}\text { I wore koko and } \\
\text { high water pants and } \\
\text { had a black mark on } \\
\text { the forehead. His } \\
\text { wife wore a large } \\
\text { size of black robe } \\
\text { and veil without } \\
\text { wearing any make } \\
\text { up. }\end{array}$ \\
\hline 9 & inale, & $\begin{array}{l}\text { B was sociable, } \\
\text { expressionless, } \\
\text { kept the distance } \\
\text { from others, and } \\
\text { had sharp eye } \\
\text { gaze. His wife was } \\
\text { reclusive, had } \\
\text { ordinary } \\
\text { expression and } \\
\text { gaze. }\end{array}$ & $\begin{array}{l}\text { B's voice was } \\
\text { moderate, his } \\
\text { intonation was flat, } \\
\text { and his rhythm } \\
\text { was moderate. } \\
\text { Meanwhile, his } \\
\text { wife had low voice } \\
\text { with moderate } \\
\text { intonation. }\end{array}$ & $\begin{array}{l}\text { He wore koko and } \\
\text { high water pants and } \\
\text { had a black mark on } \\
\text { the forehead. His } \\
\text { wife wore a large } \\
\text { size of black robe } \\
\text { and veil without } \\
\text { wearing any make } \\
\text { up }\end{array}$ \\
\hline 10 & $\begin{array}{l}\text { E, male, } 34 \text {. } \\
\text { (the } \\
\text { interview is } \\
\text { represented } \\
\text { by his wife) }\end{array}$ & $\begin{array}{l}\text { E's wife was } \\
\text { reclusive; her eyes } \\
\text { were empty full of } \\
\text { sadness. }\end{array}$ & $\begin{array}{l}\text { E's wife had slow } \\
\text { and low voice } \\
\text { volume with } \\
\text { moderate rhythm }\end{array}$ & $\begin{array}{l}\text { E's wife wore a } \\
\text { large size of dark } \\
\text { veil and robe } \\
\text { without wearing any } \\
\text { make up. She wore } \\
\text { niqab. }\end{array}$ \\
\hline 11 & $\begin{array}{l}\text { male, } \\
\text { (the }\end{array}$ & $\begin{array}{ll}\text { D's wife } & \text { was } \\
\text { reclusive } & \text { and }\end{array}$ & $\begin{array}{l}\text { he voice of D's } \\
\text { vife had rather }\end{array}$ & $\begin{array}{l}\text { She wore a large } \\
\text { size of dark veil and }\end{array}$ \\
\hline
\end{tabular}


A Study of Religious Symbols Attached to The

Former Terrorist Convicts' Family as Seen in

Arini Indah Nihayaty, Social Interaction

\begin{tabular}{|l|l|l|l|l|}
\hline $\begin{array}{l}\text { interview is } \\
\text { represented } \\
\text { by his wife) }\end{array}$ & distracted. & $\begin{array}{l}\text { loud with } \\
\text { moderate rhythm } \\
\text { and moderate } \\
\text { intonation. }\end{array}$ & $\begin{array}{l}\text { robe without } \\
\text { wearing any make } \\
\text { uphe wore niqab. }\end{array}$ \\
\hline
\end{tabular}

During the interview, the informants' similarities with each other are observed by monitoring their nonverbal communication. The resemblances of behavior during interview are the reclusiveness and the reluctance to be interviewed. Informant $\mathrm{Y}$ said that he actually did not like being questioned about his past because it actually caused trauma and gave no advantages to him. Some informants were unwelcome to the interviewer's visit. However, the interviewer explained the goal of the visit is to build a good relation with them as well as to assist them as assigned by the Ministry of Religious affair.

In the interview, there was a tendency for the informants to produce low volume with moderate intonation when discussing children and family matters, but they tended to speak loudly and firmly when discussing religion and the state. In addition, informants from Surabaya and Malang have similarities in wearing clothes. Almost all male informants wore high water pants, had beards and had black marks on their foreheads. FN was quite different because he wore ordinary attire. As for their wives, they mostly wear large size of robe and veil. Specifically, informant $\mathrm{T}$ did not have a wife.

Informants from Probolinggo, W, I, B, E, and D, have similarities, both men and women. The man wears high water pants, a robe / koko, had beard and had a black mark on the forehead. Women have similarities in wearing large size of robes and veil and a dark niqab which is different from the family of former terror convicts from Surabaya and Malang.

This study finds similarities and differences in the usage of religious symbols in the family of these former terrorist convicts. From the observations, the similarities of these families are their basic of thought, especially in the past they believed that their acts of terror were justified by religion. Meanwhile, a number of differences found on them are reinforced by the involvement of their present environment. Leather (in Jalaludin, 2000: 298) concludes research on faces as follows: (1) The face communicates judgments with happy and unhappy expressions; (2) The face communicates interest or disinterest in other people or the environment; (3) The face communicates the intensity of involvement in a situation; (4) the face communicates the level of individual control over his own statements; and (5) The face communicates the presence or lack of understanding. Religious symbols that appear in the daily lives of the family of ex-terrorist convicts are seen from the choice of attire. Man wears high water pants, robe and has beard. Woman wears large size of dark robe and veil. Some wear a niqab.

In addition to symbols in dressing with distinctive features, the places to study religion are not public schools but exclusive ones, even some of them choose to 
homeschool. Of all the informants studied, almost all of their children attend the Integrated Islamic School. Besides, those who choose homeschooling have specific reason. The wife of informant $\mathrm{W}$, whose three children chose homeschooling, stated that she did not believe in public schools. Moreover, she had a fear that public school delivered outside influence to the children, so she and her husband chose to teach them at home.

The strategy of the family in cultivating religious values affects the choice of education method for their children. Most of them prefer to send their children to nonformal schools. Some choose to educate themselves through a strategy known as "home education" (UK) and "homeschooling" (United States), "sekolah rumah" (Indonesia). In implementing alternative teaching in home, mother often becomes the main educator. Family based, home based, with parents as the main person in charge of their children's education. ${ }^{44}$

Education with its various forms and models is a strategy in transmitting values, including religious values. ${ }^{45}$ Flexible and practical learning strategies of homeschooling encourage resilience for the transmission and cultivation of radical religious values. Homeschooling has the potential to create a "spiral of encapsulations" that further takes children away from common values.

Education in the family of ex-terrorist convicts is pretty alike. They have such strong beliefs and ideologies that are difficult to change which is seen from the expectations for their children. Their attitudes and behaviors are regarded different from others which make them barely socialize with people outside their group. This is reflected by their choice of institution to learn religion, such as Mushola At-Tauhid Probolinggo and an education foundation near the mosque. The two places were founded by group that is suspected as radical group.

The education system run in these two places employs its own curriculum which does not refer to the regulation of Ministry of Education and culture or Ministry of Religious Affairs. In this place, former terror convicts plan the activities. Next to the foundation is a field as a place to test the homemade bombs. This field is also a place to teach archery; one of the teacher is former terrorist I from Probolinggo. At-Tauhid Mushola and its Education Foundation are reclusive and exclusive. Based on observations and interviews with a number of people around those institutions, Counterterrorism Special Detachment 88 had raided the area.

The religious symbol of the family of former terrorist convicts can also be seen from the pictures and writings as a medium that shows hatred for the government. The rehabilitation of a prisoner is by risk, need, and responsiveness. So,

${ }^{44}$ Brian D. Ray, "Homesschoolingassociated With Beneficial Learner And Societal Outcomes Buteducatorsdo Not Promote It,” Peabody Journal Of Education 88, no. 3 (2013): 324.

${ }^{45}$ Guruh Ryan Aulia, "Pengaruh Pendidikan Pancasila Dan Kewarganegaraan Terhadap Sikap Kepedulian Sosial," Jurnal Ushuluddin: Media Dialog Pemikiran Islam 23, no. 1 (2021): 105. 
identifying an individual in a terrorist movement is from three components; motivation, ideology, and capability. ${ }^{46}$

The components of motivation include economy, law, society, situation, superiority and self-actualization. The ideological components consist of doctrine, attitudes, target of the mission, group networks, militancy, philosophy and context. Then, the capability component includes intelligence, language skills, drawing skills, fighting skills, social domination, ability to operate machines and electronics. In fact, almost all former terrorist convicts have certain skills, such as informants I and W who have ability to operate machines and electronics, informants $\mathrm{AF}$ who is an expert in languages, and informant $Y$ has drawing skills.

The nonverbal symbols from informants and their families can also be observed from their WhatsApp status and the messages they share to the interviewer on a certain occasions. Four phenomena have become their major concern recently. First, the government has criminalized a number of figures whom they consider as ulama. Second, the lawsuit against injustice committed by the police and the government. Third, government stipulates the inconsistent policy on "mudik Eid homecoming ban" (exodus) while opening the door for foreigners to enter the country. Fourth, in the context of an Islamic Holiday, President delivered statement which encouraged people to eat roast pork that are forbidden in Islam. In conclusion, they have tendency to disagree with the policies of the current government.

In general, the verbal and nonverbal religious symbols in former terrorist convicts and their families depict their differences with other people in the community. This also causes these former terrorist convicts and their families hardly socialize with others outside their group. Besides, their different attitudes and behaviors also build boundaries in the social interaction. Moreover, their interpretation in the concept of Islam is also different. The concepts of jihad, hijrah, thaghut, shahid, amaliah, ist'dad, Al-Bara, Al-Wala, takfiri are the embraced doctrines that are difficult to change.

All family members of former terrorist convicts have not removed their religious symbols. It means the religious symbols used in the past, especially by the heads of families who are also former terrorist convicts, are still embraced today. Some of the ex-terrorist's family members are even still taking exclusive education, not public school. Although, some of them choose religion-based public schools. Schools or educational methods, as discussed in this study, are also included as religious symbols. These religious symbols and ideas are still presented by the families of former terrorist convicts when interacting with others.

46 Arie W. Kruglanski et al., "Fully Committed: Suicide Bombers Motivation And The Quest For Personal Significance," Political Psychology 30, no. 3 (2009): 331-357. 
Arini Indah Nihayaty, Bagong Suyanto, Sutinah
A Study of Religious Symbols Attached to The

Former Terrorist Convicts' Family as Seen in

\section{E. Conclusion}

Families of former terrorist convicts still use religious symbols when interacting in society. They, intentionally or not, display such image. Although they do not have the potential to take a radical action, their depicted symbols and image, in the context of discourse, are seen as their radical thinking by public. This research can be continued by exploring the methods to minimize the radicalism potential that may still exist within them. The involvement of families in acts of terrorism in Indonesia is not a novel phenomenon. The family has a central function in Darul Islam, Jamaah Islamiyah with its various organizational variants and ISIS. From various interviews conducted by researchers, it can be concluded that all members of the family (children, wife, husband, and relatives) are still strong in maintaining the usage of the certain religious symbols in the socialization process. Thus, the efforts to educate the families of former terrorist convicts need to be continued. Therefore, resilience in the family is needed to strengthen these ex-convict families so that they do not return to their group. The cause of their weakness is due to their economic problems (after leaving the prison), psychological conditions (trauma), as well as social, cultural, and religious circumstances. Therefore, it is expected the government, NGOs and the community guide them to the positive paths. The help is not only financial support, but also a family-friendly rehabilitation program that includes identifying risks, needs, and responsiveness to the family of ex-terrorist convicts in order to help them return to multicultural society and be dedicated to the Republic of Indonesia.

\section{BIBLIOGRAPHY}

Adler, Ronald B, and George Rodman. Understanding Humas Communication. New York: Oxford University Press, 2014.

Amri, Muhammad, Risna Mosiba, and Saidna Zulfiqar Bin-Tahir. "Interreligious Tolerance in the Perception of Maluku Muslim Society." Jurnal Adabiyah 20, no. 1 (2020): 178-195.

Aulia, Guruh Ryan. "Pengaruh Pendidikan Pancasila Dan Kewarganegaraan Terhadap Sikap Kepedulian Sosial." Jurnal Ushuluddin: Media Dialog Pemikiran Islam 23, no. 1 (2021): 105.

Berger, Peter L. The Social Construction of Reality. Palatine: Anchor Book, 1966.

Burgess, Ernest W. "The Family As A Unity Of Interacting Personalities." The 
Family 7, no. 1 (1926): 3.

Dillistone, F.W. Daya Kekuatan Simbol. Yogyakarta: Kanisius, 2002.

Driver, Michael J., and Siegfried Streufert. "Integrative Complexity: An Approach to Individuals and Group as Information-Processing Systems." Administrative Science Quarterly 14, no. 2 (1969): 272.

Durkin, K. Developmental Social Psychology From Infancy To Old Age. New York: Blackwell Publisher Inc, 1995.

Erikson, Erik H. Childhood and Society. New York: WW Norton \& Company, 1993.

Fatiyah. "Pemahaman Santri Terhadap Nilai-Nilai Pancasila." Jurnal Adabiyah 17, no. 1 (2017): 44.

Geertz, Hildred. Keluarga Jawa. Jakarta: Grafiti Press, 1973.

Halse, Rolf. "The Muslim-American Neighbour as Terrorist: The Representation of a Muslim Family in 24." Journal of Arab \& Muslim Media Research 5, no. 1 (2012): 3 .

Hequembourg, Amy L., and Michael P. Farrell. "Lesbian Motherhood: Negotiating Marginal-Mainstream Identities.” Gender \& Society 13, no. 4 (1999): 540.

Hoffman, Bruce. Inside Terrorism. Columbia: Columbia University Press, 2017.

Hugo, Graeme. "Effects of International Migration on the Family in Indonesia." Asian and Paciific Migration Journal 11, no. 1 (2002): 13-46.

Jailani, Abdul Qodir, and R. F. Rachman. "Kajian Semiotik Budaya Masyarakat: Nilai Keislaman Dalam Tradisi Ter-Ater Di Lumajang." MUHARRIK: Jurnal Dakwah dan Sosial 3, no. 2 (2020): 125-137.

Kruglanski, Arie W., Edward Orehek, Xiaoyan Chen, and Mark Dechesne. "Fully Committed: Suicide Bombers Motivation And The Quest For Personal Significance." Political Psychology 30, no. 3 (2009): 331-357.

Lauren, Shapiro R., and John Jay. "Women's Radicalization to Religious Terrorism: An Examination of ISIS Cases in the United States." Islamic States Online Activity and Response 42, no. 1-2 (2019): 88.

Mead, Goerge Herbert. Mind, Self and Society: From a Standpoint of Social Behaviorist. Edited by Charles W. Morris. Chicago: University of Chicago Press, 1934.

Meltzer, Bernard N. "Meads Social Psychology." In Symbolic Interaction: A Reader in Social Psychology, edited by Jerome G. Manis and Bernard N. Meltzer, 38. Boston: Allyn \& Bacon, 1978. 
Arini Indah Nihayaty, Bagong Suyanto, Sutinah
A Study of Religious Symbols Attached to The

Former Terrorist Convicts' Family as Seen in

Mulyana, Deddy. Metodologi Penelitian Kualitatif: Paradigma Bari Ilmu Komunikasi Dan Ilmu Sosial Lainnya. Bandung: Remaja Rosdakarya, 2018.

Nelson, Lindsey D. "Herbert Blumer's Symbolic Interactionism. University of Colorado at Boulder Spring." Colorado.Edu. Last modified 1998. Accessed January 5, 2020. http://www.colorado.edu/ Communication /metadiscourses/Papers/ App_Papers/Nelson.htm.

Nihayaty, Arini Indah, and Atikah Mardhiya Rohmy. "Pemanfaatan Media Sosial Komunitas Untuk Menghadapi Konten Islam Ekstrim Di Internet." Dakwatuna: Jurnal Dakwah dan Komunikasi Islam 6, no. 2 (2020): 213-227.

Nihayaty, Arini Indah, and Bagong Suyanto. "Strategi Pembinaan Mental Masyarakat Dalam Menghadapi Radikalisme." Al-Tazkiah: Jurnal Bimbingan dan Konseling Islam 9, no. 2 (2020): 95-112.

Nirwana, Andi, and Muhammad Rais. "Toleransi Antar Umat Beragama Islam Dan Kristen Pada Masyarakat Kelurahan Paccinongang Kecamatan Somba Opu Kabupaten Gowa." Jurnal Al Adyaan; Jurnal Sosial dan Agama 6, no. 2 (2020): 185.

Piliang, Yasraf Amir. Hipersemiotik: Tafsir Cultural Studies Atas Matinya Makna. Yogyakarta: Jalasutra, 2003.

Puspitawati, Herien. Gender Dan Keluarga: Konsep Dan Realita Di Indonesia. Bogor: PT Penerbit IPB Press, 2012.

Rachman, R. F. "Perspektif Karen Armstrong Tentang Islamofobia Di Media Barat." Dakwatuna: Jurnal Dakwah dan Komunikasi Islam 4, no. 2 (2018): 282-291.

Rahman, Abd. "Family Resilience in Islamic Perspective (A Case Study of Parent and Child Interaction Behavior in the District of Somba Opu Gowa)." Jurnal Adabiyah 20, no. 2 (2020): 351.

Rakhmat, Jalaluddin. Psikologi Komunikasi. Bandung: PT. Remaja Rosdakarya, 2000.

Ray, Brian D. "Homesschoolingassociated With Beneficial Learner And Societal Outcomes Buteducatorsdo Not Promote It." Peabody Journal Of Education 88, no. 3 (2013): 324.

Ridwan, N.K. Agama Borjuis: Kritik Atas Nalar Islam Murni. Yogyakarta: Aruzz, 2004.

Ritzer, George, and Douglas J. Goodman. Teori Sosiologi: Dari Teori Sosiologi Klasik Sampai Perkembangan Mutakhir Teori Sosial Posmodern. Yogyakarta: Kreasi Wacana, 2010.

Rohmy, Atikah Mardhiya, Teguh Suratman, and Arini Indah Nihayaty. "Peranan Tentara Nasional Indonesia Dalam Penindakan Terorisme Berbasis Agama.” 
AT-TURAS: Jurnal Studi Keislaman 7, no. 1 (2020): 86-112.

Rose, Arnold Marshall. "A Summary of Symbolic Interaction Theory." In Theories and Paradigms in Contemporary Sociology, edited by R. Serge Denisoff, 13. Itasca: F. E. Peacock, 1974.

Santrock, John W. Perkembangan Anak. Jakarta: PT Erlangga, 2007.

Shibutani, Tamotsu. Society and Personality. Englewood Cliffs: Prentice Hall, 1961.

Suyanto, Bagong, Mun'im Sirry, and Rahma Sugihartati. Pseudo-Radicalism and the De-Radicalization of Educated Youth in Indonesia Studiesin Conflict \& Terrorism. London: Routledge \& Kegan Paul, 2019.

Tajibu, Kamaluddin. "Pasang Ri Kajang in Developing Youth Character of Environmental Love in Tana Toa Kajang." Jurnal Adabiyah 20, no. 1 (2020): 131.

Turner, Bryan. Teori Sosial: Dari Klasik Sampai Postmodern. Yogyakarta: Pustaka Pelajar, 2012.

Umar, Nasaruddin. "Reindonesianisasi Pemahaman Islam." Detik News. Last modified 2020. https://news.detik.com/kolom/d-4870589/reindonesianisasipemahaman-islam.

Umiarso, and Elbadiansyah. Interaksionisme Simbolik Dari Klasik Hingga Modern. Jakarta: PT. Raja Grafindo Persada, 2014.

Interaksionisme Simbolik Dari Klasik Hingga Modern. Jakarta: PT Raja Grafindo Persada, 2014.

Wajdi, Firdaus. "Globalization and Transnational Islamic Education: The Role of Turkish Muslim Diaspora in Indonesian Islam.” Jurnal Adabiyah 18, no. 2 (2018): 176.

Zara, Ayten. Grief Intensity, Coping and Psychological Health among Family Members and Friends Following a Terrorist Attack, Death Studies. London: Routledge \& Kegan Paul, 2019. 


\section{Guidelines}

\section{Submission of Article}

urnal Adabiyah welcomes the articles submission with the main themes on Humanities and Islamic Studies with the emphasis on interdisciplinary and intertextuality approach. Adabiyah is thematicly published twice in a year. ie the theme of the humanities in June and the Islamic Study in December.

Themes related to Islamic Studies are textual studies, scriptural traditions, Islamic law, and theology; and those related to Humanities are language, literature, history, and culture. This scholarly journal Guarantees that the editor decision based on the peer review results will not exceed 30 days from the paper submission date.

Authors are invited to read our archives; to find the relevant topics for the journal, and to submit complete unpublished scientific researches, which are not under review in any other conferences or academic journal.

\section{PUBLICATION ETHIC}

Publication Ethic and Malpractice Statement

Jurnal Adabiyah is a peer-reviewed journal, published twice a year by the Faculty of Adab and Humaniora, Alauddin State Islamic University of Makassar Indonesia. It is available online as open access sources as well as in print. This statement clarifies ethical behaviour of all parties involved in the act of publishing an article in this journal, including the author, the editor-in-chief, the Editorial Board, the reviewers, and the publisher. This statement is based on COPE's Best Practice Guidelines for Journal Editors.

Ethical Guideline for Journal Publication

The publication of an article in Jurnal Adabiyah, is an essential building block in the development of a coherent and respected network of knowledge. It is a direct reflection of the quality of the work of the authors and the institutions that support them. Peer-reviewed articles support and embody the scientific methods. It is therefore important to agree upon standards of expected ethical behavior for all parties involved in the act of publishing: the author, the editor, the reviewer, the publisher, and the society. As the publisher of Jurnal Adabiyah, the Faculty of Adab and Humaniora takes its duties of guardianship over all stages of publishing seriously and it recognizes its ethical and other responsibilities. The Faculty of Adab and Humaniora committed to ensuring that advertising, reprint or other commercial revenue has no impact or influence on editorial decisions.

\section{Publication Decisions}

The editors of Jurnal Adabiyah is responsible for deciding which articles submitted to the journal should be published. The validation of the work in question and its importance to researchers and readers must always drive such decisions. The editors may be guided by the policies of the journal's editorial board and constrained by such legal requirements as shall then be in force regarding libel, copyright infringement, and plagiarism. The editors may confer with other editors or reviewers in making their decisions.

\section{Plagiarism Screening}

It is basically author's duty to only submit a manuscript that is free from plagiarism and academically malpractices. The editor, however, will check all submitted papers through Turnitin.

\section{Fair Play}

An editor at any time evaluates manuscripts for their intellectual content without regard to race, gender, sexual orientation, religious belief, ethnic origin, citizenship, or political philosophy of the authors. 


\section{Confidentiality}

The editors and any editorial staff must not disclose any information about a submitted manuscript to anyone other than the corresponding author, reviewers, potential reviewers, other editorial advisers, and the publisher, as appropriate.

\section{Disclosure and Conflicts of Interest}

Unpublished materials disclosed in a submitted manuscript must not be used in editors' own research without the express written consent of the author.

\section{DUTIES OF AUTHORS}

\section{Reporting Standards}

Authors of reports of original research should present an accurate account of the work performed as well as an objective discussion of its significance. Underlying data should be represented accurately in the paper. A paper should contain sufficient detail and references to permit others to replicate the work. Fraudulent or knowingly inaccurate statements constitute unethical behaviour and are unacceptable.

\section{Originality and Plagiarism}

The authors should ensure that they have written entirely original works, and if the authors have used the work and/or words of others that this has been appropriately cited or quoted.

\section{Multiple, Redundant, or Concurrent Publication}

An author should not in general publish manuscripts describing essentially the same research in more than one journal or primary publication. Submitting the same manuscript to more than one journal concurrently constitutes unethical publishing behaviour and is unacceptable.

\section{Acknowledgement of Sources}

Proper acknowledgment of the work of others must always be given. Authors should cite publications that have been influential in determining the nature of the reported work.

\section{Authorship of the Paper}

Authorship should be limited to those who have made a significant contribution to the conception, design, execution, or interpretation of the reported research. All those who have made significant contributions should be listed as co-authors. Where there are others who have participated in certain substantive aspects of the research project, they should be acknowledged or listed as contributors. The corresponding author should ensure that all appropriate co-authors and no inappropriate co-authors are included on the paper, and that all co-authors have seen and approved the final version of the paper and have agreed to its submission for publication.

\section{Disclosure and Conflicts of Interest}

All authors should disclose in their manuscript any financial or other substantive conflict of interest that might be construed to influence the results or interpretation of their manuscript. All sources of financial support for the project should be disclosed.

\section{Fundamental errors in Published Works}

When an author discovers a significant error or inaccuracy in his/her own published work, it is the author's obligation to promptly notify the journal editor or publisher and cooperate with the editor to retract or correct the paper.

\section{PLAGIARISM}

It is basically author's duty to only submit a manuscript that is free from plagiarism and academically malpractices. The editor, however, will check all submitted papers through Turnitin. 


\section{AUTHOR GUIDELINES}

\section{Guidelines for online submission:}

1. Author should first register as Author to the website of Jurnal Adabiyah. Click the menu "register" to register as an author.

2. Once after the author is registered, please login to the website of Jurnal Adabiyah and submit the article through online submission (with the stat us of active submissions).

3. The article should follow the standard template of Jurnal Adabiyah provided in the website.

4. The citation and bibliography should follow the Turabian citation style.

5. Author is restricted not to send his/her article to another journal before having confirmation from the editorial team (approximately 4 weeks right after the article submitted).

6. Author should follow editorial decisions and recommendations related to the article completion. All reviews and assessements will be informed through online submission.

Article submitted to Jurnal Adabiyah editorial board must follow these guidelines:

1. Article should be based on the scientific research in the field humanities and Islamic studies;

2. Article must be an original work and has not been previously published;

3. Article should be written in Arabic or English languages;

4. Article must be typed in one-half spaced on A4-paper size;

5. Article's length is about $6,000-10,000$ words;

6. All submission must include a 150-250 word abstract;

7. Abstract should be written in 3 languages; Arabic, English, and Bahasa;

8. Full name(s) of the author(s) must be stated, along with his/her/their institution and complete address;

9. All submission should be in OpenOffice, Microsoft Word, RTF, or WordPerfect document file format;

10. Bibliographical reference must be noted in footnote and bibliography according to Jurnal Adabiyah style. In addition, it is suggested for author(s) to use reference manager tools such

\section{as MENDELEY or 7 otero}

When a source is cited for the first time, full information is provided: full name(s) of author(s), title of the source in italic, place of publication, publishing company, date of publication, and the precise page that is cited. For the following citations of the same source, list the author's last name, two or three words of the title, and the specific page number(s). The word ibid., op.cit., and loc.cit. are may not be used any more.

\section{Example in footnotes:}

${ }^{1}$ Mircea Eliade (ed.), The Encyclopedia of Religion, vol. 8 (New York: Simon and Schuster, 1995), h. 18.

${ }^{2}$ Norman Daniel, Islam and the West (Oxford: One World Publications, 1991), h. 190.

${ }^{3}$ Syeikh Ja'far Subhāni, Mafăhim Al-Qur'ān (Beirut: Mu'assasah Al-Tarīkh Al-'Arabī, 2010)., Juz 5, h. 231. 
${ }^{4}$ Syeikh Ja'far Subhānī, Mafāhim Al-Qur'ān, h. 8-9.

\section{Example in bibliography:}

Subhānī, Syeikh Ja'far. Mafăhim Al-Qur'ān. Beirut: Mu'assasah Al-Tarīkh Al-’Arabī, 2010.

Eliade, Mircea (ed.). The Encyclopedia of Religion, vol. 8. New York: Simon and Schuster, 1995.

Daniel, Norman. Islam and the West. Oxford: One World Publications, 1991.

Shihab, Muhammad Quraish. Sunnah-Syiah Bergandengan Tangan: Mungkinkah? Kajian Atas Konsep Ajaran Dan Pemikiran. Cet. III. Jakarta: Lentera Hati, 2007.

\section{Detail informations of the footnotes:}

1. Holy book

Al-Qur'ân, Al-Baqarah/2: 185.

Perjanjian Baru, Mrk. 2: 18.

2. Qur'anic translation

${ }^{1}$ Departemen Agama RI, al-Qur'an dan Terjemahannya (Jakarta: Darus Sunnah, 2005), h. 55.

3. Book

${ }^{1}$ Muḥammad 'Ajjaj al-Khațib, Ușl al-Hadith: 'Ulumuh wa Mușțalaḥ uh (Beirut: Dâr al-Fikr, 1989), h. 57.

4. Translation Books

${ }^{1}$ Toshihiko Izutsu, Relasi Tuhan dan Manusia: Pendekatan Semantik terhadap al-Qur'an, terj. Agus Fahri Husein dkk (Yogyakarta: Tiara Wacana, 2003), h. 14.

5. Voluminous book

${ }^{1}$ Muḥammad al-Ṭâhir b. 'Ashur, al-Tahrīir wa al-Tanwīr, Vol. 25 (Tunisia: Dâr al-Suhûn, 2009), h. 76.

${ }^{1}$ Muḥammad b. Ismā‘īl al-Bukharī, al-Jami‘ al-Ṣaḥịh, Vol. 2 (Beirut: Dar al-Kutub al-‘Ilmı́yah, 1999), h. 77.

6. Article in book

${ }^{1}$ Sahiron Syamsuddin, "Metode Intratekstualitas Muhammad Shahrur dalam Penafsiran al-Qur'an" dalam Abdul Mustaqim dan Sahiron Syamsuddin (eds.), Studi al-Qur'an Kontemporer: Wacana Baru Berbagai Metodologi Tafsir (Yogyakarta: Tiara Wacana, 2002), h. 139.

7. Article in encyclopaedia

${ }^{1}$ M. Th. Houtsma, "Kufr" dalam A. J. Wensinck, at al. (ed.), First Encyclopaedia of Islam, Vol. 6 (Leiden: E.J. Brill, 1987), h. 244.

8. Article in journal

${ }^{1}$ Muhammad Adlin Sila, "The Festivity of Maulid Nabi in Cikoang, South Sulawesi: Between Remembering and Exaggerating the Spirit of Prophet", Studia Islamika 8, no. 3 (2001): h. 9.

9. Article in mass media

${ }^{1}$ Masdar F. Mas'udi, "Hubungan Agama dan Negara”, Kompas, 7 Agustus 2002. 
10. Article in Internet

${ }^{1}$ Muhammad Shahrūr, "Reading the Religious Teks: a New Approach" dalam http://www.shahrour.org/25 Februari 2010/diakses 5 Juni 2010.

11. Thesis or dissertation

${ }^{1}$ Syahruddin Usman, "KinerjaGuru Penddikan Agama Islam pada SMAN dan SMKN Kota Makassar”, Disertasi (Makassar: PPs UIN Alauddin, 2010), h. 200.

\section{COPYRIGHT NOTICE}

Authors who publish with this journal agree to the following terms:

1) Authors retain copyright and grant the journal right of first publication with the work simultaneously licensed under a Creative Commons Attribution License that allows others to share the work with an acknowledgement of the work's authorship and initial publication in this journal.

2) Authors are able to enter into separate, additional contractual arrangements for the non-exclusive distribution of the journal's published version of the work (e.g., post it to an institutional repository or publish it in a book), with an acknowledgement of its initial publication in this journal.

3)Authors are permitted and encouraged to post their work online (e.g., in institutional repositories or on their website) prior to and during the submission process, as it can lead to productive exchanges, as well as earlier and greater citation of published work (See The Effect of Open Access). 